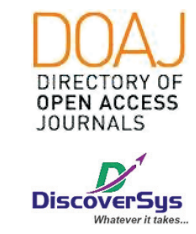

Published by DiscoverSys

\section{Tetrasiklin HCL gel 0,7\% meningkatkan jumlah sel fibroblas dan mempertebal ligamen periodontal pada sulkus gingiva tikus yang mengalami periodontitis}

\author{
I Gusti Agung Sri Pradnyani
}

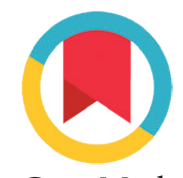

CrossMark

\title{
ABSTRACT
}

Periodontal disease is an infectious disease, could be result loose of the teeth. This research is to prove that the applying $0.7 \%$ tetracycline hcl gel on rat gingival sulcus result higher number of fibroblasts and collagen synthesis which are marked by the thicker of rat periodontal ligament. The study was a randomized post test only control group design experimental study on 32 white male rats which are inducted by lipopolyssaccaride (LPS) for 8 days. And then rats divided into control group were given placebo, and treatment group were given $0.7 \%$ tetracycline $\mathrm{HCL}$ gel. On 10th days, the rats were euthanazided for taken mandibula alveolar bone tissue sampling and histological preparations were made by HE (Harris Hematoxylin-Eosin) staining. The data were analyzed using SPSS program processed using Shapiro
Wilk for normality test and then continued using independent t-test. The result of this research is the mean number of fibroblasts at treatment group by administration of $0.7 \%$ tetracycline $\mathrm{HCL}$ gel (148.38 \pm 5.11 units) was higher than the control group (113.19 \pm 5.39 units). The mean of collagen synthesis was showed by the thickness of periodontal ligamen at group treated $0.7 \%$ tetracycline $\mathrm{HCL}$ gel $(338.65 \pm 57.28 \mu \mathrm{m})$ was higher than the control group $(225.50 \pm 45.29 \mu \mathrm{m})$. The mean number of fibroblast cell and thickness of periodontal ligament were statistically different $(p<0.05)$. Thus, it is concluded that $0.7 \%$ tetracycline $\mathrm{HCL}$ gel enhance the number of fibroblasts cell and the thickness of periodontal ligament in rat with periodontal disease.

Keywords: tetracycline $\mathrm{HCL}$ gel, number of fibroblasts cell, periodontal ligament, periodontal disease

Cite This Article: I Gusti Agung Sri Pradnyani. 2017. Tetrasiklin HCL gel 0,7\% meningkatkan jumlah sel fibroblas dan mempertebal ligamen periodontal pada sulkus gingiva tikus yang mengalami periodontitis. Intisari Sains Medis 8(1): 14-18. D0I: 10.1556/ism.v8i1.3

\section{ABSTRAK}

Periodontitis merupakan penyakit infeksi, apabila tidak dilakukan perawatan yang tepat dapat mengakibatkan tanggalnya gigi. Pemberian tetrasiklin $\mathrm{HCL}$ gel $0,7 \%$ pada sulkus gingiva mengakibatkan jumlah sel fibroblas dan pembentukkan kolagen pada ligamen periodontal lebih banyak yang ditandai dengan bertambahnya lebar ligamen periodontal tikus. Penelitian eksperimental Randomized Post Test Only Control Group Design pada 32 ekor tikus putih jantan yang diinduksi lipopolisakarida (LPS) selama 8 hari. Lalu tikus dibagi menjadi kelompok control yang diterapi dengan placebo dan kelompok perlakuan yang diterapi dengan tetrasiklin HCL gel 0,7\%. Pada hari ke-10 tikus dieuthanasia untuk pengambilan mandibula dan dibuatkan preparat histologi dengan pengecatan HE. Data diuji normalitas dengan Shapiro-wilk dan dilanjutkan dengan independent $t$-test. Rerata jumlah fibroblas kelompok perlakuan dengan pemberian tetrasiklin $\mathrm{HCL}$ gel $0,7 \% \quad(148,38 \pm 5,11$ unit) lebih tinggi dibandingkan dengan rerata kelompok kontrol (113,19 $\pm 5,39$ unit). Rerata peningkatan kolagen yang ditunjukkan ketebalan ligamen periodontal kelompok perlakuan dengan pemberian tetrasiklin HCL gel $0,7 \%(338,65 \pm 57,28 \mu \mathrm{m})$ lebih tinggi dibandingkan rerata kelompok kontrol $(225,50 \pm 45,29 \mu \mathrm{m})$. Hasil rerata jumlah fibroblas dan ketebalan ligamen periodontal ini berbeda secara bermakna $(p<0,05)$. Disimpulkan bahwa tetrasiklin $\mathrm{HCL}$ gel $0,7 \%$ meningkatkan jumlah fibroblas dan ketebalan ligamen periodontal tikus yang mengalami periodontitis. Perlu dilakukan penelitian lebih lanjut terhadap peran tetrasiklin gel sebagai conditioning agent pada permukaan akar gigi terhadap peningkatan kolagen ligamen periodontal, dan perlu dilakukan aplikasi tetrasiklin $\mathrm{HCL}$ gel pada pasien penderita periodontitis untuk melihat proses penyembuhan periodontitis secara klinis.
Sri Pradnyani, Program Magister IImu Biomedik Universitas Udayana gspradnyani81@gmail.com

Diterima: 1 September 2016. Disetujui: 13 September 2016. Diterbitkan: 02 Januari 2017
Kata Kunci: tetrasiklin HCL gel 0,7\%, jumlah fibroblas, ligamen periodontal

Cite Pasal Ini: I Gusti Agung Sri Pradnyani. 2017. Tetrasiklin HCL gel 0,7\% meningkatkan jumlah sel fibroblas dan mempertebal ligamen periodontal pada sulkus gingiva tikus yang mengalami periodontitis. Intisari Sains Medis 8(1): 14-18. D0I: 10.1556/ism.v8i1.3 


\section{PENDAHULUAN}

Penyakit periodontal banyak diderita oleh manusia hampir di seluruh dunia, dan biasanya penderita datang untuk mendapat perawatan saat keadaan sudah parah seperti adanya kegoyangan gigi sehingga gigi sulit untuk dipertahankan.

Menurut hasil survey kesehatan gigi dan mulut di Jatim tahun 1995, penyakit periodontal terjadi pada 459 orang di antara 1000 penduduk dan lebih banyak di pedesaan daripada perkotaan. Prevalensi dan intensitas penyakit periodontal di Asia dan Afrika terlihat lebih tinggi daripada di Eropa, Amerika dan Australia. Penyakit periodontal menduduki urutan kedua utama di Indonesia yang masih merupakan masalah di masyarakat. ${ }^{1}$

Periodontitis atau penyakit yang menyerang pada gingiva dan jaringan pendukung gigi ini merupakan penyakit infeksi yang serius dan apabila tidak dilakukan perawatan yang tepat dapat mengakibatkan kehilangan gigi. Penumpukan bakteri plak pada permukaan gigi merupakan penyebab utama penyakit periodontal, trutama golongan bakteri gram negatif anerob. Bakteri tersebut akan mengeluarkan toksin lipopolisakarida (LPS) yang selanjutnya toksin ini dapat menginduksi kejadian - kejadian seluler di jaringan periodontal khususnya pada tulang alveolar. ${ }^{2}$

Ligamen periodontal menghubungkan gigi ke tulang rahang dan juga menopang gigi pada soketnya dan menyerap beban yang mengenai gigi. Matriks metalloproteinase yang meningkat pada keadaan periodontitis, dapat menyebabkan kerusakan kolagen pada jaringan periodontal termasuk pada daerah ligament peridontalnya, dimana sangat banyak terdapat serat kolagen yang mendukung jaringan ini. Penurunan sintesis kolagen fibrosa juga dapat menyebabkan kehilangan perlekatan jaringan periodontal, yang dalam gambaran histologis diperlihatkan dengan kerusakan pada ligamen periodontal. $^{3}$

Tetrasiklin telah digunakan secara luas pada perawatan penyakit periodontal. Tetrasiklin mempunyai kemampuan untuk berkonsentrasi pada jaringan dan menghambat pertumbuhan Actinobacillus actinomycetemcomitans, dan mampu merangsang suatu efek antikolagenase sehingga dapat menghambat terjadinya kerusakan jaringan dan mungkin membantu regenerasi tulang. ${ }^{4}$ Pemberian tetrasiklin atau metronidazol dalam waktu singkat atau pemakaian tetrasiklin secara oral dengan alat irigasi yang lambat ternyata menyebabkan sangat berkurangnya jumlah flora subgingiva. ${ }^{5}$

Penggunaan antibiotika golongan tetrasiklin dalam terapi periodontal telah dimodifikasi secara kimia sebagai obat antimikrobial, antikolagenase dan anti inflamasi. Tetrasiklin sebagai anti kolagenase digunakan $16 \mathrm{mg} / \mathrm{ml}$ mampu menghambat aktivitas kolagenase kurang lebih 90\% dibanding ampisilin yang tidak efektif menghambat enzim kolagenase. Pemberian tetrasiklin dapat menghantarkan suatu konsentrasi yang dapat diterima 10 hari pada sedikitnya $640 \mathrm{mg} / \mathrm{ml}$ pada cairan di dalam sulkus. ${ }^{6}$

Biokompatibilitas penggunaan tetrasiklin telah diteliti dalam bentuk tetrasiklin gel dengan konsentrasi $0,7 \%$ yang dapat diterima jaringan dan dapat menghilangkan lapisan smir, membuka tubuli dentin dan membuka matrix kolagen. ${ }^{6}$

Tetrasiklin juga dapat mempengaruhi hasil perawatan, karena selain sebagai antibiotik berspektrum luas, juga memiliki efek non-antibiotik dalam terapi penyakit periodontal, di antaranya: menghambat enzim kolagenase, menghambat resorpsi tulang, dan efek langsung pada penyebaran dan perlekatan sel fibroblas. ${ }^{7}$

\section{AHAN DAN METODE}

Jenis penelitian ini adalah penelitian eksperimental randomized posttest only control group design. Sampel yang digunakan adalah tikus putih jantan (Ratus novergicus) jumlahnya 32 ekor dan dibagi dalam 2 kelompok, yaitu kelompok kontrol yang diinduksi LPS kemudian diberikan placebo, dan kelompok perlakuan diinduksi LPS kemudian diberikan Tetrasiklin $\mathrm{HCl} \mathrm{Gel} \mathrm{0,7 \% .}$

Gel dibuat dengan menimbang CMC-Na sejumlah $500 \mathrm{mg}$ ditambahkan aquadest $10 \mathrm{ml}$. Gerus CMC-Na dengan aquades di dalam mortir sampai terbentuk mucilage. Lalu timbang tetracycline sejumlah $70 \mathrm{mg}$ dan gerus ke dalam mucilage di dalam mortir hingga homogen. ${ }^{8}$

Infeksi pada jaringan periodontal tikus dilakukan dengan induksi LPS pada sulkus gingiva pada daerah labial incisivus sentral rahang bawah tikus putih jantan sebanyak $5 \mu \mathrm{g}$ dalam $0,05 \mathrm{ml}$ PBS satu kali sehari selama delapan hari (Indahyani et al., 2010). Untuk memudahkan aplikasi bahan, sebelumnya setiap tikus dianastesi menggunakan kombinasi xylazin $(5 \mathrm{mg} / \mathrm{kg}$ BB) dan ketamin $(20 \mathrm{mg} / \mathrm{kg} \mathrm{BB})$ secara intraperitoneal (Amin dkk., 2013). Dalam delapan hari diharapkan akan terjadi periodontitis (Indahyani dkk., 2010). Ditandai dengan kemerahan dan pembengkakan pada gingival, kehilangan perlekatan gingival terhadap tulang alveolar dan poket yang dalam.

Tetrasiklin $\mathrm{HCl}$ gel 0,7\% dimasukan ke dalam sulkus gingiva tikus kelompok perlakuan, sedangkan pada kelompok kontrol diberikan gel placebo. Tetrasiklin HCL gel dimasukan ke dalam sulkus gingiva sampai penuh dan keluar dari dalam sulkus, sebanyak sekali sehari. Tikus dieuthanasia pada hari ke-10 menggunakan eter secara inhalasi, 
lalu diambil mandibula tikus. Mandibula tikus dimasukkan dalam pot yang berisi buffer formalin Berdasarkan hasil pemeriksaan histologis 10\% selanjutnya dibuat sediaan mikroskopis.

Banyaknya fibroblas dinilai dengan menghitung fibroblas yang aktif (memiliki sitoplasma yang besar, kromatin halus, nucleus ovoid dan tampak nyata) pada ligamen periodontal tikus yang telah dibuat preparat dengan pengecatan Harris Hematoxylin Eosin. Dilihat pada lima lapang pandang menggunakan mikroskop elektrik dengan pembesaran 400X dan Olympus DP12 Digital Camera. Hitung jumlah fibroblas pada tiap lapang pandang, kemudian dijumlahkan dan diambil rata-ratanya.

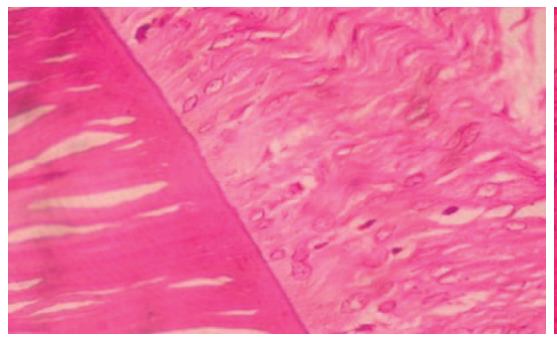

A

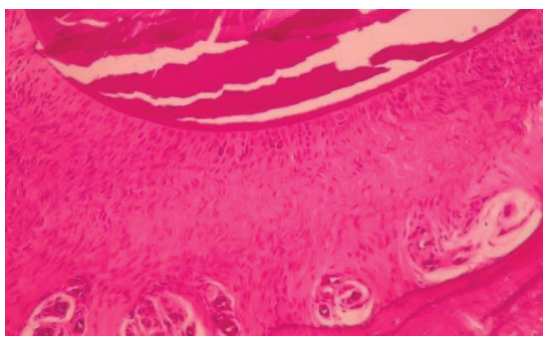

B
Gambar 1 Gambaran histologis sel fibroblas pada kelompok kontrol (A), dan pada kelompok perlakuan (B), Pengambilan gambar dilakukan dengan mikroskop elektrik Olympus CX21 pembesaran $400 \mathrm{x}$

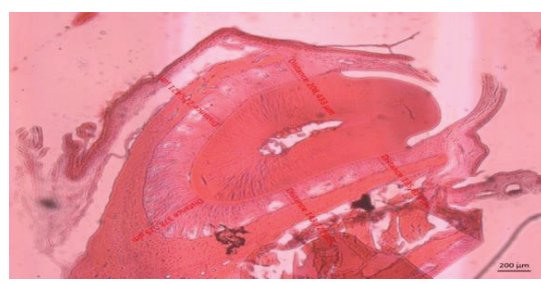

A

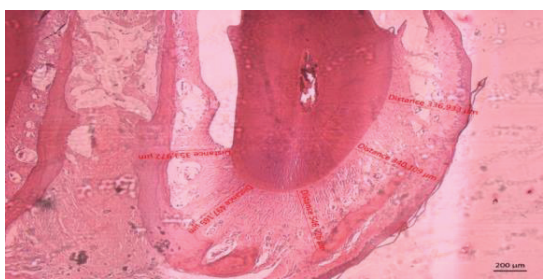

B
Gambar 2 Gambaran histologis tebal ligamen periodontal pada kelompok kontrol (A), dan pada kelompok perlakuan (B). Pengambilan gambar dilakukan dengan mikroskop elektrik Olympus CX21 pembesaran 400x

Tabel 1 Rerata jumlah fibroblas antar kelompok

\begin{tabular}{lcccc}
\hline Kelompok & $\mathbf{n}$ & Rerata & SB & p \\
\hline Kontrol & 16 & 113,19 & 5,39 & 0,000 \\
Perlakuan & 16 & 148,38 & 5,11 & \\
\hline
\end{tabular}

Tabel 2 Rerata ketebalan ligamen periodontal antar kelompok

\begin{tabular}{llccc}
\hline Kelompok & $\mathbf{n}$ & Rerata & SB & p \\
\hline Kontrol & 16 & 225,50 & 45,9 & 0,000 \\
Perlakuan & 16 & 338,65 & 57,28 & \\
\hline
\end{tabular}

Ketebalan kolagen ligamen periodontal dilihat pada potongan melintang pada tiga lapang pandang dengan menggunakan mikroskop elektrik merk Olympus CX21 dengan pembesaran 400X, kemudian diambil rata-ratanya. Untuk morfometri menggunakan Olympus DP12 Digital Camera.

\section{HASIL}

Berdasarkan hasil pemeriksaan histologis dan perhitungan statistiK, diperoleh hasil sebagai berikut:

Tabel 1 menunjukkan bahwa rerata jumlah fibroblas kelompok kontrol adalah 113,19 sel per 5 lapang pandang, rerata kelompok perlakuan tetrasiklin HCL gel adalah 148,38 sel per 5 lapang pandang. Analisis kemaknaan dengan independent $t$-test nilai $\mathrm{p}=0,000$ berarti rerata jumlah fibroblas antar kelompok berbeda bermakna $(p<0,05)$.

Tabel 2 menunjukkan bahwa rerata ketebalan ligamen periodontal kelompok kontrol adalah 225,50 per 5 lapang pandang, rerata kelompok perlakuan tetrasiklin HCL gel adalah 338,65 per 5 lapang pandang. Analisis kemaknaan dengan independent $t$-test nilai $\mathrm{p}=0,000$ berarti bahwa rerata ketebalan ligamen periodontal antar kelompok berbeda bermakna $(\mathrm{p}<0,05)$.

\section{PEMBAHASAN}

Uji perbandingan rerata jumlah fibroblas antar kelompok menggunakan uji independent $t$ - test, menunjukkan terdapat perbedaan jumlah sel fibroblas yang signifikan pada kelompok kontrol dan kelompok perlakuan $(\mathrm{p}<0,05)$ yang disajikan pada Tabel 1. Terdapat peningkatan jumlah fibroblas yang bermakna pada kelompok perlakuan Tetrasiklin HCL gel 0,7\% dibandingkan kelompok kontrol pada pengamatan hari ke-10. Hal ini berarti bahwa proses penyembuhan jaringan periodontal yang lebih baik, terjadi pada kelompok yang diberikan tetrasiklin HCL gel 0,7\% sebagai conditioning agent ke dalam sulkus gingiva.

Hasil penelitian ini didukung oleh penelitian Silva et al., 2016 dimana perlekatan sel fibroblas pada specimen gigi yang dioleskan tetracycline gel lebih baik dibandingkan kelompok kontrol yang hanya mendapatkan perlakuan skalling dan root planning saja, kelompok perlakuan yang mendapatkan EDTA, dan kelompok yang mendapatkan asam sitrat. Pengamatan tentang perlekatan sel fibroblas ini dilakukan 24 jam setelah perlakuan dengan tetrasikin gel, diamati dengan scanning electron microscopy (SEM) dengan perbesaran 3000X.

Terjadinya peningkatan jumlah sel fibroblas pada penelitian ini dapat disebabkan oleh karena 
penggunaan tetrasiklin HCL gel sebagai conditioning agent membantu memberikan lingkungan yang sesuai untuk fase penyembuhan tahap awal seperti terbukanya matriks kolagen dan meningkatkan perlekatan fibroblas. ${ }^{9}$

Uji perbandingn rerata lebar ligamen periodontal antar kelompok menggunakan uji independent t-test, menunjukkan terdapat perbedaan ketebalan ligamen periodontal yang signifikan pada kelompok kontrol dan kelompok perlakuan $(\mathrm{p}<0,05)$ yang disajikan pada tabel 2. Terdapat peningkatan ketebalan ligamen periodontal yang bermakna pada pengamatan hari ke-10. Pada kelompok perlakuan, ligamen periodontal lebih tebal dibandingkan dengan kelompok kontrol. Hal ini berarti pembentukkan kolagen lebih banyak pada kelompok yang diberikan tetrasiklin HCL gel sebagai conditioning agent ke dalam sulkus gingiva dibanding kelompok kontrol.

Pembentukkan kolagen pada penelitian ini sesuai dengan penelitian yang dilakukan oleh Terranova et al., (2006) yang menyimpulkan bahwa pemberian tetrasiklin HCL sebagai conditioning agent meningkatkan aktivitas osteoblas, pembentukkan kolagen dan tulang dimana proses- proses tersebut terhambat saat terjadi periodontitis. ${ }^{10}$

Tetrasiklin HCL adalah antibiotik yang efektif melawan bakteri pathogen periodontal dimana senyawa ini diserap permukaan akar gigi dan dikeluarkan perlahan-lahan dalam bentuk aktif. Sebagai conditioning agent, tetrasiklin menghasilkan aksi yang potensial untuk meningkatkan penyembuhan periodontal dan regenerasi, termasuk di dalamnya yaitu demineralisasi permukaan akar gigi dan menghilangkan smear layer, stabilisasi fibrin clot, meningkatkan kemotaksis, adhesi dan pertumbuhan fibroblas, menghambat enzim matrix metalloproteinase. ${ }^{11}$

Penyakit periodontal menyebabkan kehilangan perlekatan jaringan periodontal dan sementum terpapar lingkungan rongga mulut, sehingga terjadi akumulasi plak, pembentukan kalkulus gigi, hilangnya struktur kolagen, dan menyebabkan menurunnya kemampuan pertumbuhan sel dan juga kelangsungan hidup fibroblas yang berperan dalam regenerasi atau pembentukan perlekatan jaringan yang baru. ${ }^{12}$ Permukaan akar gigi yang terpapar akibat periodontitis menjadi hipermineralisasi, terkontaminasi oleh endotoksin bakteri dan substansi aktif biologis lainnya. Demineralisasi sementum akar gigi merupakan salah satu tahapan penting dalam terapi periodontal regeneratif. ${ }^{13}$ Sementum merupakan jaringan termineralisasi dengan fungsi utama sebagai jalur masuknya serabut ligamen periodontal pada permukaan akar gigi. ${ }^{14}$ Tujuan dari demineralisasi permukaan akar gigi pada terapi periodontal regeneratif adalah menghilangkan smear layer, mengurangi jumlah bakteri dan endotoksin, juga mengekspos serabut kolagen pada sementum. ${ }^{15}$ Konsep biologis dari proses demineralisasi permukaan akar gigi adalah membantu adhesi jendalan darah ke serabut kolagen yang terekspos, sehingga berperan sebagai pendukung terjadinya pembentukan perlekatan jaringan ikat baru. ${ }^{11}$

Fibroblas merupakan sel utama untuk sintesis kolagen. Tahap pertama sintesis berada pada intraseluler, untuk menghasilkan prokolagen dimana dalam keadaan aktif berada diruang ekstraseluler. Sintesis di intraseluler terjadi di nucleus dimana gen-gen diaktifkan dan terjadi perubahan mRNA, khas untuk rantai polipeptida tunggal, mRNA masuk kedalam sitoplasma dan diubah pada ribosom dari reticulum endoplasma dan secara simultan terjadi sintesis rantai polipeptida triple. Tiga rantai a yang identik sebagai kolagen tipe III dan tiga rantai yang bereda sebagai tipe I. Prokolagen selanjutnya meninggalkan sel, kemudian beberapa asam amino membelah secara enzimatik membentuk tropokolagen. Tropokolagen inilah yang secara definitive disebut molekul kolagen. Molekul-molekul ini secara spontan bersatu kedalam fibril-fibril yang selanjutnya mengalami cross-linking kebentuk yang lebih tebal atau bundle. Kolagen disintesis oleh fibroblast, kondroblas, otot polos, sel endotel dan sel epitel. ${ }^{16}$ Pada penelitian ini terjadi peningkatan jumlah sel fibroblas dan kolagen pada ligamen periodontal tikus yang mengalami periodontitis dan telah diterapi dengan terasiklin HCL gel 0,7\% sebagai conditioning agent. Hal ini dapat disebabkan karena tetrasiklin mampu menciptakan lingkungan yang baik untuk penyembuhan seperti tetrasiklin meningkatkan ikatan fibronektin yang akan menstimulasi perlekatan dan pertumbuhan sel fibroblas, lalu sel fibroblas menghasilkan kolagen, dan tetrasiklin juga menghambat matrix metalloproteinase (MMP) yang dapat merusak protein structural dari ekstraselular matriks.

\section{SIMPULAN}

Dari hasil penelitian dan analisis data dapat disimpulkan Pemberian tetrasiklin HCL gel 0,7\% pada sulkus gingiva tikus yang mengalami periodontitis mengakibatkan jumlah sel fibroblas lebih banyak dan ligamen periodontal lebih tebal.

\section{DAFTAR PUSTAKA}

1. Depkes RI. 2000. Jawa Timur Dalam Angka. Laporan Survey Kesehatan Rumah Tangga. hal 52-54.

2. Amin, M. N., Meilawaty, Z., Sandrasari, D. 2010. Prospek Probiotik dalam Pencegahan Agresivitas 
Resorpsi Osteoklastik Tulang Alveolar yang Diinduksi Lipopolisakarida pada Penyakit Periodontal. Dentika Dental Journal 15 (2): 150 -3.

3. Isna Afifaya, Nur Permatasari, Robinson Pasaribu. 2011. Efek Pemberian Ekstrak Metanol Daun Ciplukan (Physalis minima L) terhadap Lebar Ruang Ligamen Periodontal Tikus Putih (Rattus novergicus) Strain Wistar Pasca Ovariektomi. Jurnal PDGI

4. Jolkozsky, D. L., Ciancio, S. 2006. Chemoteraphy Agent. In: Clinical Periodontology. $10^{\text {th }}$ ed. Missouri: Saunders Elsevier

5. Manson, J. D., Eley, B. M. 2004. Periodontics. $5^{\text {th }}$ ed. United Kingdom : Elsevier. P. $154-8$

6. Wahyukundari, M. A. 2009. Perbedaan Kadar Matrix Metalloproteinase-8 Setelah Skaling Dan Pemberian Tetrasiklin Pada Penderita Periodontitis Kronis. Jurnal PDGI vol. 58. No.1

7. Wood, N.H, S. J. Botha. 2003. Effect of Tetracycline on Proliferation and Collagen Production of Human Gingival Fibroblast. University of Pretoria. South Africa

8. Rowe, R. C. 2009. Excipients Handbook of Pharmaceutical. $6^{\text {th }}$ ed. London: Pharmaceutical Press

9. Silva, A. C., Moura, C. C., Ferreira, J. A., Magalhaes, D., Dechichi, P., Soares, P. B. 2016. Biological Effects of a Root Conditioning Treatment On Periodontally Affected Teeth - An In Vitro Analysis. Braz. Dent. J. Vol. 27. No. 2

10. Terranova V. P., Franzetti L. C., Di Florio, R. M., Lyall R. M., Wikesjo, U. M., Baker, P.J., Christersson, L.A., Genco, R.J. 2006. Tetracycline Treatment of Dentin Promotes Fibroblast Adhesion and Growth. J Periodont Res; 21: 330- 337
11. Ishi, E. P., Dantas, A. R., Batista, L. H., Onotre, M. A., Sampaio, J. E. 2008. Smear Layer Removal and Collagen Fiber Exposure Using Tetracycline Hydrochloride Conditioning. The Journal of Contemporary Dental Practice. Vol. 9. No. 5

12. Chahal, G. S., Chhina, K., Chhabra, V., Bhatnagar, R., Chahal, A. 2014. Effect of Citric Acid, Tetracycline, And Doxycycline On Instrumented Periodontally Involved Root Surfaces: A SEM Study. J. Indian Soc Periodontal. Jan-Feb; 18(1): 32-37

13. Bosshardt, D. D., Sculean, F. 2009. Effect of Enamel Matrix Proteins On Tissue Formation Along the Roots of Human Teeth. J. Periodontal R. April, 40(2): 158-67

14. Newman, M. G. 2006. The Normal Periodonsium. In: Carranza's Clinical Periodontology. $9^{\text {th }}$ Ed. Philadelpia: W. B. Saunder Co.

15. Shetty, B., Dinesh, A., Seshan, H. 2008. Compatitive Effects of Tetracyclines and Citric Acid On Dentin Root Surface of Periodontally Involved Human Teeth: A Scanning Electron Microscope Study. I Indian Soc Periodontal. Jan-Apr; 12(1): 8-15

16. Mandal, Ananya. 2012. Asam Amino Dalam Pembentukkan Kolagen. http://www.news- medical.net/health/CollagenSynth. Accsessed 4 Desember 2013.

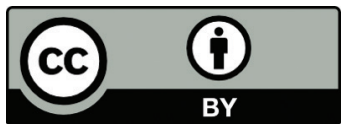

This work is licensed under a Creative Commons Attribution 